\title{
Symmetric Potentiometric Cells for the Measurement of Unified pH Values
}

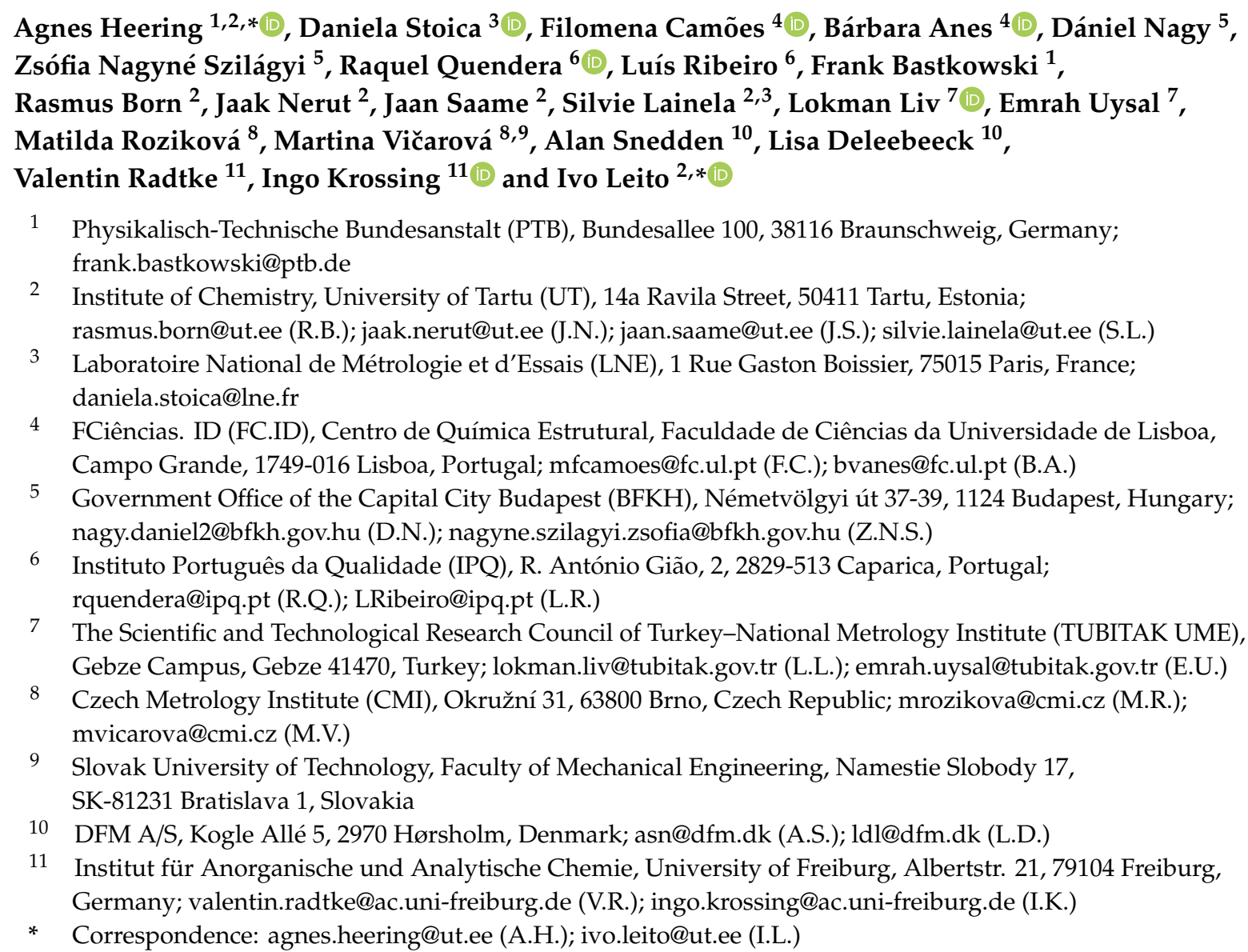

\begin{abstract}
A unified $\mathrm{pH}$ scale of absolute values $\left(\mathrm{pH}_{\mathrm{abs}}\right.$ scale) enables the comparison of acidities in different solvents. To date, very few different experimental setups have been used for the measurement of values on this scale. The article describes the design and performance of the different symmetric cells used for unified $\mathrm{pH}$ measurement by several institutions. Well-established and reliable standard aqueous buffer solutions are the first step of method validation necessary to achieve a robust metrological level for more complex media. The $\mathrm{pH}$ of aqueous standard buffers was measured by differential potentiometry, where the potential between two glass electrodes is measured directly. All the tested electrochemical cells prove to be suitable for unified $\mathrm{pH}$ measurements. This validation highlights that the method is, to a large extent, independent of the used equipment, including the cell geometry. The inherent symmetry of the cell design helps to reduce the experimental workload and improve the accuracy of obtained results.
\end{abstract}

Keywords: unified $\mathrm{pH}$ scale; pHabs; all solvents; differential potentiometry; liquid junction; ionic liquid 


\section{Introduction}

$\mathrm{pH}$ is a measure of acidity. $\mathrm{pH}$ in a given solvent, termed $\mathrm{pH}_{\mathrm{S}}$, is defined [1] through the activity of the solvated $\mathrm{H}^{+}$as follows:

$$
\mathrm{pH}_{\mathrm{S}}=-\lg a_{\mathrm{H}^{+}, \mathrm{S}}=-\lg \left(\frac{m_{\mathrm{H}^{+}} \gamma_{\mathrm{H}^{+}, \mathrm{S}}}{m^{\ominus}}\right)
$$

$a_{\mathrm{H}^{+}, S}$ is the relative activity [2] of the solvated proton in the solvent $\mathrm{S}$ in the molality scale, $m_{\mathrm{H}^{+}}$is the proton molality, $\gamma_{\mathrm{H}^{+}, S}$ is the activity coefficient of the proton in the molality scale and $m^{\ominus}=1 \mathrm{~mol} \mathrm{~kg}^{-1}$ is the standard molality. An individual $\mathrm{pH}_{\mathrm{S}}$ scale is defined solely for a given solvent due to the dependence of the standard state on the solvent properties.

Potentiometry is a method used in electroanalytical chemistry [3] that links the measured potential, $E$, of a chosen cell to the activity of a chemical species of interest via the Nernst equation. Thus, potentiometry is ideal for the measurement of $\mathrm{pH}$ and is the de facto standard technique for this task. The primary $\mathrm{pH}$ measurement method [1] uses the hydrogen gas electrode as the $\mathrm{H}^{+}$-sensitive indicator electrode for the assignment of $\mathrm{pH}$ values to reference solutions. In contrast, the glass electrode, with an aqueous gel layer on the glass surface, highly selective to $\mathrm{H}^{+}$, is the most widespread sensor for secondary and routine $\mathrm{pH}$ measurements. Either of these electrodes are typically used in asymmetric cells where the potential of the indicator electrode $\left(\mathrm{H}^{+}\right.$-sensitive) is measured against a reference electrode (cell I).

(I) Indicator electrode|Solution 1|Salt bridge|Solution 2|Reference electrode.

The indicator electrode is sensitive to the analyte ion $\left(\mathrm{H}^{+}\right.$in this case), while the reference electrode is not sensitive to the composition of the tested solution and has constant potential. The reference electrode is usually a silver-silver chloride electrode in a potassium chloride $(\mathrm{KCl})$ solution with constant concentration (typically $\geq 3.5 \mathrm{~mol} \mathrm{dm}^{-3}$ ), responding to chloride ion, $\mathrm{Cl}^{-}$. A double liquid junction established by a salt bridge between both sample and reference solutions, completes the cell [4]. Such electrochemical cells are acknowledged to work well in aqueous solutions.

Potentiometry in non-aqueous solvents has several limitations [4], compared to water, e.g., the scarcity of suitable electrodes, both indicator and reference, with steady and reproducible potentials and the unknown size of the potential drop at the liquid junction(s). In the case of $\mathrm{pH}$ measurements, there is also a shortage of calibration standards [5-13].

Nevertheless, $\mathrm{pH}$ measurements in nonaqueous solutions have been attempted, and there are reported values. However, since the definition links $\mathrm{pH}$ in a given solvent to a standard state defined for that specific solvent [1], values obtained in different solvents cannot be compared. The shifts in the standard states of the different solvents are not well-established and, consequently, $\mathrm{pH}$ values measured in different solvents are not comparable when using the established methodologies [5-13]. There exist several acidity functions [14], but these still suffer from the same incomparability problem.

In contrast, acidities in different solvents, measured according to the recently introduced methodology that leads to a unified acidity scale of absolute $\mathrm{pH}$ values $\left(\mathrm{pH}_{\mathrm{abs}}\right.$ scale) [15], can be compared. For this scale, the standard state is universal and is not linked to any individual solvent: it is defined as the theoretically well-described ideal proton gas at 1 bar and $298.15 \mathrm{~K}$. This proton gas is taken as the standard state (zero point) of the scale and every solvent or their mixtures are linked to this standard state via the Gibbs energy of solvation of the proton. The $\mathrm{pH}_{\mathrm{abs}}$ values are subsequently shifted by a constant value to align the actual $\mathrm{pH}_{\mathrm{abs}}$ values with the conventional $\mathrm{pH}$ values of the aqueous $\mathrm{pH}$ scale, obtaining the so-called $\mathrm{pH}_{\text {abs }}^{\mathrm{H}_{2} \mathrm{O}}$ values [16]:

$$
\mathrm{pH}_{\mathrm{abs}}^{\mathrm{H}_{2} \mathrm{O}}=-\frac{\Delta_{\text {solv }} G^{\ominus}\left(\mathrm{H}^{+}, \mathrm{S}\right)}{R T \ln 10}+\mathrm{pH}_{\mathrm{S}}+\frac{\Delta_{\text {solv }} G^{\ominus}\left(\mathrm{H}^{+}, \mathrm{H}_{2} \mathrm{O}\right)}{R T \ln 10}
$$

where $R$ is the molar gas constant, $T$ is the absolute temperature and $\Delta_{\text {solv }} G^{\ominus}\left(\mathrm{H}^{+}, \mathrm{S}\right)$ is the Gibbs 
energy of solvation of the proton in the solvent. This equation can be simplified with the help of Gibbs energy of transfer ${ }^{\left(\Delta_{\mathrm{tr}} G^{\ominus}\right)}$ from water to solvent $S$ to

$$
\mathrm{pH}_{\mathrm{abs}}^{\mathrm{H}_{2} \mathrm{O}}=-\frac{\Delta_{\mathrm{tr}} G^{\ominus}\left(\mathrm{H}^{+}, \mathrm{H}_{2} \mathrm{O} \rightarrow \mathrm{S}\right)}{R T \ln 10}+\mathrm{pH}_{\mathrm{S}}
$$

The unified acidities are measured via comparisons of $\mathrm{pH}_{\text {abs }}^{\mathrm{H}_{2} \mathrm{O}}$ values of two solutions, thus obtaining $\Delta \mathrm{pH}_{\text {abs }}^{\mathrm{H}_{2} \mathrm{O}}$ values between the two solutions. When one of the solutions is a standard solution (e.g., an IUPAC (International Union of Pure and Applied Chemistry) standard $\mathrm{pH}$ buffer) with a known $\mathrm{pH}_{\mathrm{abs}}^{\mathrm{H}_{2} \mathrm{O}}$ value, then the $\mathrm{pH}_{\mathrm{abs}}^{\mathrm{H}_{2} \mathrm{O}}$ value of the second one can be easily obtained from the measured $\Delta \mathrm{pH}_{\text {abs }}^{\mathrm{H}_{2} \mathrm{O}}$.

The technique used for such measurements is differential potentiometry, measuring directly the potential between two glass electrodes immersed in the two solutions that are under comparison [16]. This approach eliminates the need for reference electrodes, but the two liquid-junction potentials (LJPs) [17] remain, although the double junction tends to minimize their contribution, through a residual value (RLJP), to the cell potential. The following symmetric cells are used:

$$
\underset{\text { GJP1 }}{\text { Glass electrode } 1 \text { SJP2 }}
$$

The salt bridge (SB) is intended to balance the charge between the half-cells. If the electroactive species, the proton in case of $\mathrm{pH}$ measurements, and its counterion were to balance the charge, their activities in the half-cells would change significantly, thus falsifying the measurement result. However, at each SB-solution interface, a LJP occurs (LJP1 and LJP2 in cell II). With the ideal salt bridge, the two LJPs cancel each other, i.e., the potential drop caused by LJPs between the half cells is zero [18]. The ideal salt bridge is symmetrical by nature. This is true for its geometry, i.e., the structures of the liquid-liquid junctions to each half-cell must be the same. This, however, is especially true for its chemical composition. The charge balance must be equally shared by both types of ions, positively and negatively charged, and the change in their chemical potentials must be equal during the process of charge balancing [19].

Conventional SBs contain dissolved electrolytes, i.e., in addition to the ions of the electrolyte, they contain a solvent. Measuring cells with different solvents in each half-cells has the disadvantage that solvent-solvent interactions at either (or even both) LJP1 or LJP2 interfaces occur between the different solvents. This affects the magnitude of the LJP contribution to the cell potential and thus inevitably breaks the symmetry. The consequence is that conventional SBs are unsuitable for potentiometric measurements between different solvents.

Ionic liquids (IL) are salts that are liquid at room temperature. They do not contain any solvents and are therefore, in principle, suitable for building an ideal SB (see below) and, by extension, an ideal ionic liquid salt bridge (ideal ILSB). Since the charge balance must be symmetrical, it follows for 1:1 IL that the transfer numbers $(t)$ of cations and anions of IL must be $t_{+}=t_{-}=0.5$ in the whole cell, i.e., in the neat IL as well as in both half-cells. Any deviation from 0.5 leads to not completely canceling LJPs. If the deviation is small in comparison to other effects, then the SB can be recognized as "ideal".

The first measurement cell on the way to experimental realization of the $\mathrm{pH}_{\mathrm{abs}}^{\mathrm{H}_{2} \mathrm{O}}$ scale was made from long Pasteur pipettes, a glass T-piece and silicone tubes (Figure 1A) [16]. The same cell was tested in a flow-through setting without a salt bridge electrolyte.

(III) Glass electrode 1|Solution 1|Solution 2|Glass electrode 2 LJP

In the flow-through setting (cell III), there was a direct junction between the test solutions that were constantly renewed. This design meant that there was a single liquid junction with no LJP minimization or cancellation. The LJP estimation was complicated even for the standard aqueous buffers with the 
(simplified) Henderson equation [4] due to the lack of literature data. Its estimation is even more complicated when solutions 1 and 2 are made in different solvents. Adding a conventional SB cancels the LJPs in the case of symmetrical cells (II), i.e., when there are very similar solutions (essentially made in the same solvent) on both sides. In other cases, a salt bridge helps to reduce the RLJP. If a SB has a sufficiently concentrated electrolyte solution $\left(0.05 \mathrm{~mol} \mathrm{dm}{ }^{-3}\right.$ tetraethylammonium perchlorate solution in acetonitrile was used), only the SB electrolyte can be considered in the estimation, which simplifies the calculations [4].

Reproducibility of the results was improved by making the salt bridge using a single piece of glass (Figure 1B) [20]. A salt bridge support made of polytetrafluoroethylene (PTFE) was tested, but it was found unsuitable. It was difficult to remove bubbles that formed during the filling of the bridge, and electrical contact was lost.

The salt bridge electrolyte was eventually switched from a salt solution to an ionic liquid [21]. Since the densities of ionic liquids are higher than most of the solutions intended to be measured, the salt bridge was redesigned from "above the measurement compartments" to "below the measurement compartments", i.e., the bottom capillary connection (See Figure 1). An ionic liquid salt bridge can also be above the solutions [22,23].

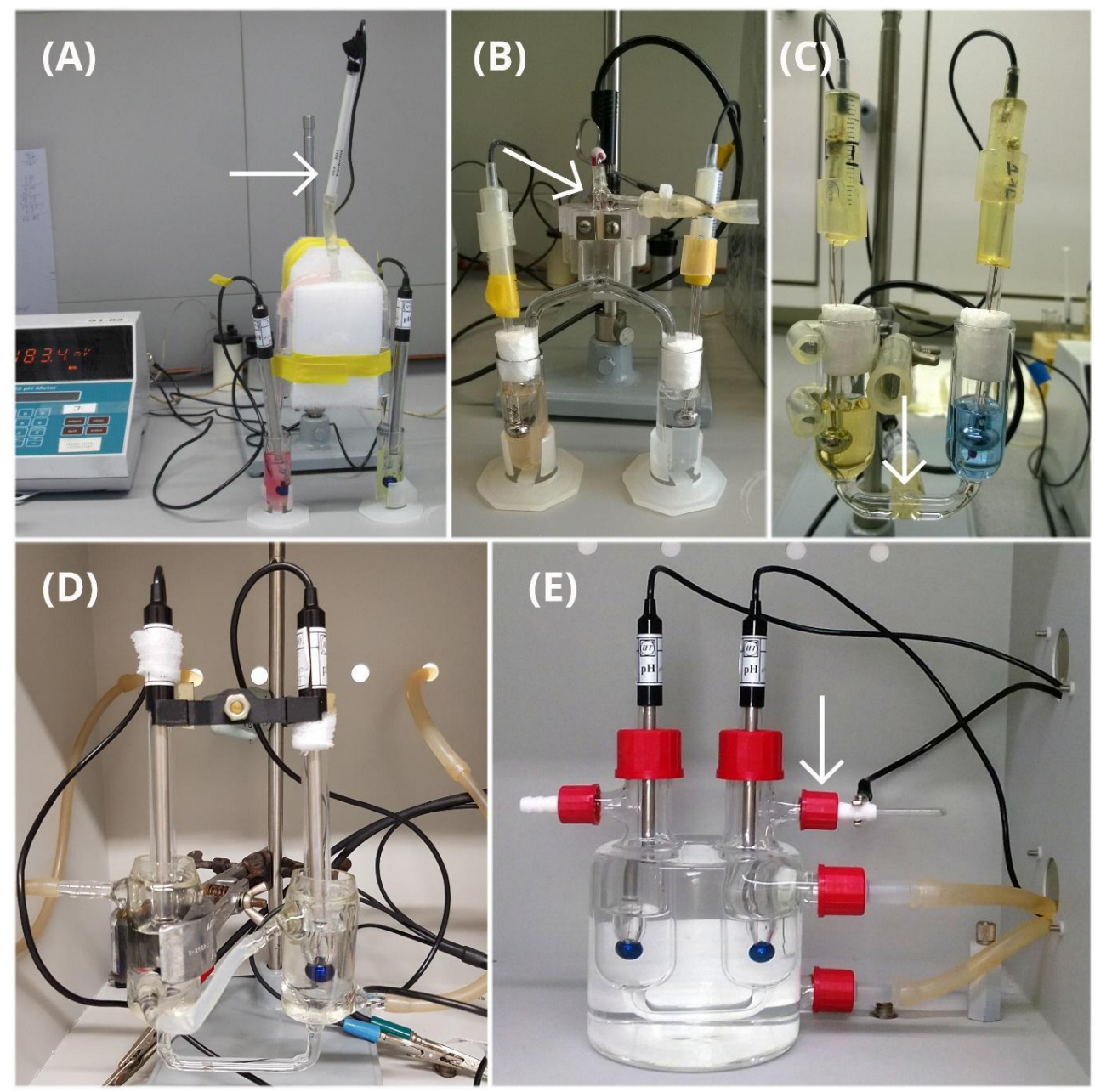

Figure 1. Cells used at University of Tartu (UT) with the salt bridge above (A and B) and below (C,D,E) the measurements compartments. (A) Cell used in [16], (B) cell used in [20], (C) cell used in [21], (D) cell used in 2018 and in [24] and (E) cell used in 2020. Arrows show the positions of the used auxiliary electrode in $(\mathbf{A}-\mathbf{C}, \mathbf{E})$. Differences in cells are given in Table A1. 
Recently [22,23,25], it was shown that for measurements of $\Delta_{\mathrm{r}} \mathrm{G}^{\ominus}\left(\mathrm{Ag}^{+}, \mathrm{S}_{1} \rightarrow \mathrm{S}_{2}\right)$ between solutions made in different solvents, by using an "ideal" ILSB, the LJP is eliminated within the consistency standard deviation (see Appendix A) corresponding to $\sim 0.1 \mathrm{pH}$ units. This standard deviation accounts for other variabilities besides the LJP, thus, LJP's contribution is less than $0.1 \mathrm{pH}$ units. Using the same system and methodology, but in the case of two solutions made in the same solvent, the LJP can be considered eliminated within the smaller consistency standard deviation. The IL used in these experiments show that the indicated degree of ideality is triethylpentylammonium bis (trifluoromethanesulfonyl) imide $\left[\mathrm{N}_{2225}\right]\left[\mathrm{NTf}_{2}\right]$.

Such symmetric setups have already found use for $\mathrm{pH}_{\mathrm{abs}}^{\mathrm{H}_{2} \mathrm{O}}$ measurements in nonaqueous solutions [21] and aqueous-organic mixtures [16,20,24]. However, comprehensive validation of their performance and investigation of influencing factors has not been carried out.

This work aims to fill the above-mentioned gap by describing the design and performance of a number of different symmetric cells used for unified acidity measurement in different research groups. The influence of cell geometry, measuring instruments, deviation from ideal symmetry, etc. were investigated. In order to obtain quantitative information about the performance of the setups at different laboratories, an interlaboratory comparison was completed in standard aqueous buffers, for which there are $\mathrm{pH}$ reference values.

The traceability and method validation are central issues for ensuring that the method is robust enough for wider adoption of the concept in the field and routine applications. For this, we firstly identify the influencing parameters with well-known and characterized solutions. Secondly, we validate the method through an interlaboratory comparison before applying the method to more complex systems. This working plan will enable discrimination between the influences coming from the sample and those from the $\mathrm{pH}_{\text {abs }}^{\mathrm{H}_{2} \mathrm{O}}$ setup.

\section{Materials and Methods}

The used ionic liquid $\left[\mathrm{N}_{2225}\right]\left[\mathrm{NTf}_{2}\right]$ was synthesized at the Krossing group of the University of Freiburg and at Iolitec GmbH (Heilbronn, Germany). The IL was used in all measurements, except in case of one set of UT measurements and measurements presented in $[16,20]$, where saturated aqueous $\mathrm{KCl}$ was used. Metal solid contact glass electrodes ECT-0601 (Izmeritelnaya tekhnika, Moscow, Russia) were used. Standard aqueous $\mathrm{pH}$ buffers were used for validation (Table 1).

Table 1. The standard aqueous buffers used for validation.

\begin{tabular}{cccc}
\hline Institution $^{a}$ & Buffer $\mathbf{p H}$ & Uncertainty $^{b}$ & Manufacturer \\
\hline BFKH & $9.180 ; 6.865 ; 4.008$ & $0.005-0.01$ & National CRMs ${ }^{c}$ \\
CMI & $9.180 ; 7.000 ; 4.000$ & 0.02 & National CRMs \\
DFM & $9.180 ; 7.000 ; 4.005$ & 0.01 & Radiometer/Hach \\
FC.ID & $9.21 ; 9.00 ; 7.00 ; 4.00$ & 0.02 & Metrohm \\
IPQ & $9.00 ; 7.00 ; 4.00$ & 0.02 & Metrohm \\
LNE & $10.012 ; 9.180 ; 7.000 ; 4.005$ & 0.01 & Radiometer/Hach \\
PTB & $9.00 ; 7.00 ; 4.01$ & 0.02 & Merck \\
TUBITAK UME & $12.00 ; 10.00 ; 7.00 ; 4.01 ; 1.68$ & 0.02 & Merck \\
UT & $10.00 ; 7.00 ; 4.00 ; 2.00$ & 0.02 & Fluka \\
\hline
\end{tabular}

${ }^{a}$ Abbreviations of institutions are explained in affiliations. ${ }^{b}$ Expanded uncertainties of the buffer $\mathrm{pH}$ values at $k=2$ level. ${ }^{c}$ CRMs are certified reference materials.

Information on the glass cells is given in Table 2, and photos of the used equipment are shown in the Supplementary Materials. All cells used now have a bottom capillary connection for the salt bridge between the two compartments containing the solutions to be compared. Published procedures $[16,21]$ were used as a starting point for procedure development and were adapted for every setup. Glass electrodes were calibrated in aqueous standard buffers and a pair with similar characteristics was chosen. If similar electrodes could not be paired, then the difference between electrodes was taken 
into account. The used $\mathrm{pH}$ meters need an auxiliary Pt electrode to work in differential potentiometry mode; otherwise, they cannot measure the potential between two glass electrodes. The position of the auxiliary electrode is not important as it can be placed anywhere in the cell. In Figure 1A the auxiliary electrode is a separate Pt electrode placed in the middle of the salt bridge. In Figure $1 \mathrm{~B}, \mathrm{C}$, it is an $\mathrm{Pt}$ wire in the middle, and in (E), it inserted from the right inlet.

Table 2. The different cells used for unified acidity measurements.

\begin{tabular}{|c|c|c|c|}
\hline Institution $^{a}$ & Water Jacket & Auxiliary Electrode & Manufacturer \\
\hline BFKH & none & Yes & $\begin{array}{l}\text { Budapest University of Technology and } \\
\text { Economics (BME, Budapest, Hungary) }\end{array}$ \\
\hline CMI & solution compartments & No & Hubert Košt'ál, Brno, Czech \\
\hline DFM & whole cell & No & Scholers Glasblæseri (Regstrup. Denmark) \\
\hline FC.ID & none & Yes & IST-UL (Lisbon, Portugal) \\
\hline IPQ & none & No & $\begin{array}{l}\text { Research Unit VICARTE, Glass and } \\
\text { Ceramics for the Arts } \\
\text { (FCT-UNL, Monte de Caparica, Portugal) }\end{array}$ \\
\hline LNE & solution compartments & No & Sklotech (Sázava, Czech) \\
\hline PTB & whole cell & No & $\begin{array}{c}\text { Gebr. Rettberg GmbH (Göttingen, } \\
\text { Germany) }\end{array}$ \\
\hline TUBITAK UME & none & Yes & LAB-CAM (İstanbul, Turkey) \\
\hline UT & $\begin{array}{c}\text { none/solution } \\
\text { compartments/whole cell }\end{array}$ & Yes/ No & $\begin{array}{l}\text { several in-house (Tartu, Estonia) and } \\
\text { commercial (Gebr. Rettberg GmbH, } \\
\text { Göttingen, Germany) cells }\end{array}$ \\
\hline
\end{tabular}

${ }^{a}$ Abbreviations of institutions are explained in affiliations.

Glass electrodes have high resistance, typically of the order of hundreds to thousands of $\mathrm{M} \Omega$, and, therefore, the minimum input impedance of the instrument must be orders of a higher magnitude, preferably $\geq 10^{13} \Omega$. Below this value, reliable measurements cannot be made. Several instruments (Table 3) were used for unified acidity measurements. If the input impedance is too low, actions can be taken to increase it, for example, the use of an impedance converter.

Table 3. The different instruments used for unified acidity measurements.

\begin{tabular}{|c|c|c|}
\hline Institution $^{a}$ & Instrument & Input Impedance $/ \Omega$ \\
\hline BFKH & Keithley 6430 Sub-Femtoamp remote sourcemeter/multimeter & $>10^{16}$ \\
\hline CMI & Bio-Logic SP200 potentiostat with a low current module & $10^{14}$ \\
\hline DFM & Zahner IM6ex potentiostat with the HiZ (high impedance) probe & $10^{15}$ \\
\hline FC.ID & Metrohm $713 \mathrm{pH}$ meter & $>10^{13}$ \\
\hline IPQ & $\begin{array}{l}\text { Agilent 3458A reference multimeter, with an impedance converter } \\
\text { based on AD8627 (PTB); } \\
\text { Keithley } 6514 \text { electrometer }\end{array}$ & $>10^{13} ;>2 \times 10^{14}$ \\
\hline LNE & Bio-Logic SP200 potentiostat with a low current module & $10^{14}$ \\
\hline PTB & Keysight B2987A Electrometer/High Resistance Meter & $>2 \times 10^{14}$ \\
\hline TUBITAK UME & $\begin{array}{c}\text { Metrohm } 916 \text { Ti-touch potentiometric titration system with } \\
\text { differential amplifier (Metrohm 6.5104.030) }\end{array}$ & $>10^{12}$ \\
\hline UT & $\begin{array}{l}\text { Gamry Reference } 3000^{\mathrm{TM}} \text { potentiostat/galvanostat/ZRA (zero } \\
\text { resistance ammeter); Metrohm } 713 \mathrm{pH} \text { meter }\end{array}$ & $>10^{14} ;>10^{13}$ \\
\hline
\end{tabular}

${ }^{a}$ Abbreviations of institutions are explained in affiliations.

The "ladder" approach, so-called because of the ladder-like schemes formed by the $\mathrm{pH}$ values and their differences [16], is used to assign unified $\mathrm{pH}$ values $\left(\mathrm{pH}_{\mathrm{abs}}^{\mathrm{H}_{2} \mathrm{O}}\right)$ to the measured solutions based on measured $\Delta \mathrm{pH}_{\text {abs }}^{\mathrm{H}_{2} \mathrm{O}}$ values between different combinations of the solutions in the cell. The $\mathrm{pH}_{\text {abs }}^{\mathrm{H}_{2} \mathrm{O}}$ values are calculated by applying a least-squares minimization technique to the measured $\Delta p H_{a b s}$ values. The consistency standard deviation of the $\mathrm{pH}$ ladder is used to evaluate the mismatch between the measured $\Delta \mathrm{pH}_{\text {abs }}^{\mathrm{H}_{2} \mathrm{O}}$ and the assigned $\mathrm{pH}_{\text {abs }}^{\mathrm{H}_{2} \mathrm{O}}$ values. Standard aqueous $\mathrm{pH}$ buffers (in an aqueous solution of $\mathrm{pH}=\mathrm{pH}_{\mathrm{abs}}^{\mathrm{H}_{2} \mathrm{O}}$ by definition) were used for validation, and buffer with a $\mathrm{pH} \approx 7$ was used as an anchor point (fixed reference $\mathrm{pH}$ value) of the $\mathrm{pH}$ ladder. A longer explanation of the ladder approach is given in the Appendix A. 


\section{Results}

\subsection{Ideal Symmetrical Conditions}

The symmetry of the system can be tested by measuring the same buffer in both compartments as in Figure 2, with a stable signal obtained rapidly after around $10 \mathrm{~min}$. The data shown in all the figures are from a specific setup, but similar results were obtained with other setups. The measured signals deviate from zero, and while the deviation depends partly on the chosen buffer, it is mostly a consequence of the difference between the electrodes. The reason is most probably the difference of slopes of glass electrodes used-this is why the potential difference depends on $\mathrm{pH}$, i.e., on the used buffer solution.

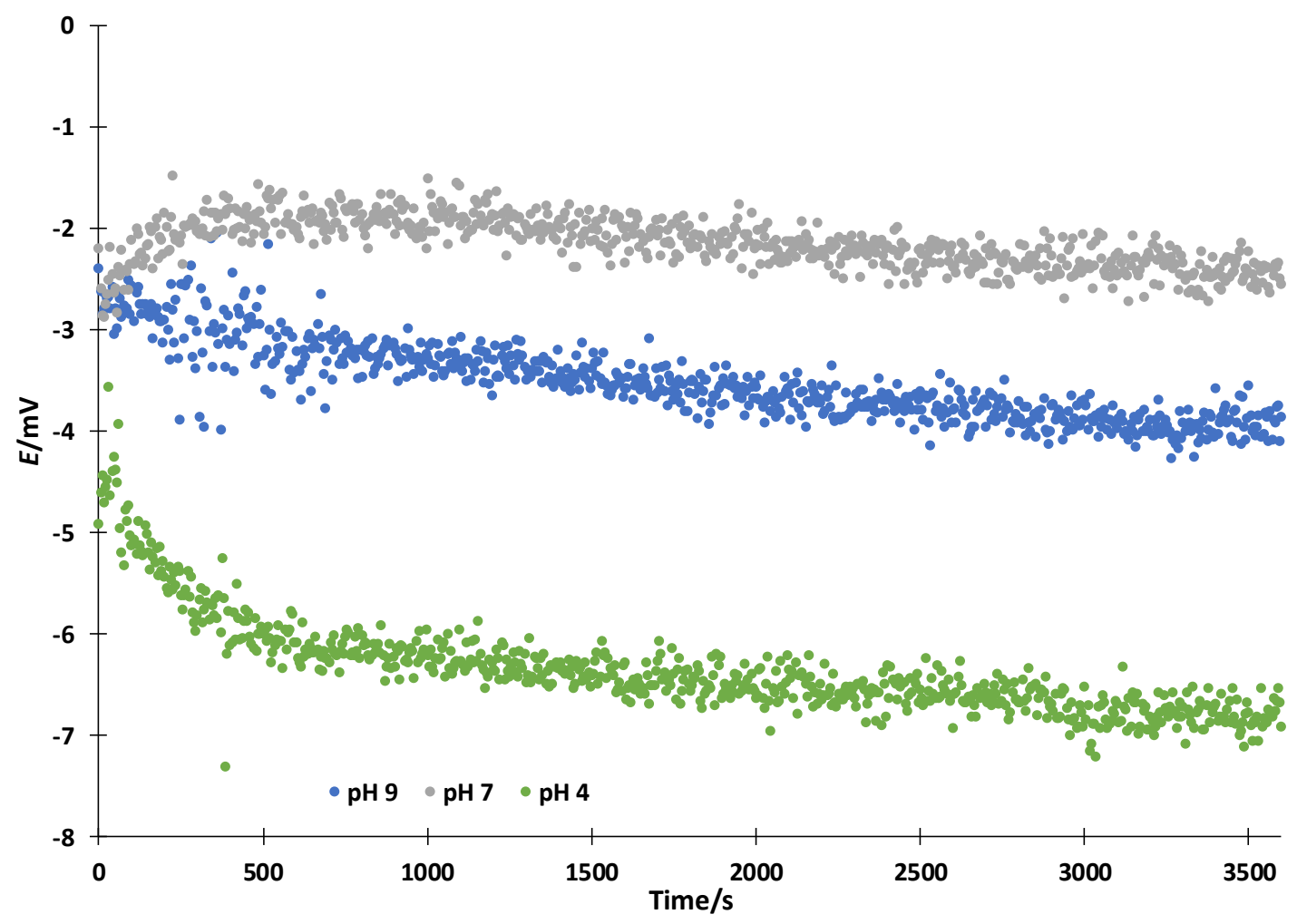

Figure 2. Time dependence of measured difference of potential without any initial stabilization time for 3 Buffer solutions with a nominal $\mathrm{pH}$ value of 4.005, 7.000 and 9.180. Measured at LNE.

\subsection{Influence of the Bubbles}

In practice, when the half cells are being filled with aqueous solutions, bubbles may appear at one or both junctions. They are caused by trapped air when filling the capillary or by some amount of air dissolved in liquids in the filling system. Due to the narrowness of the capillaries, even a very small-volume bubble can produce a relatively large impact on the measured potential. If these bubbles are not removed, the measured potential difference could be seriously affected Figure 3. Here again, the potential between the electrodes immersed in the same buffer on both sides is measured. In the presence of the bubbles at the interface between IL and the solution(s), the system needs a longer time to reach a stable potential, and sometimes the potential corresponding to situation without bubbles is never achieved. This problem can be avoided by carefully checking the junctions before measurements and removing the small bubbles if there are any. 


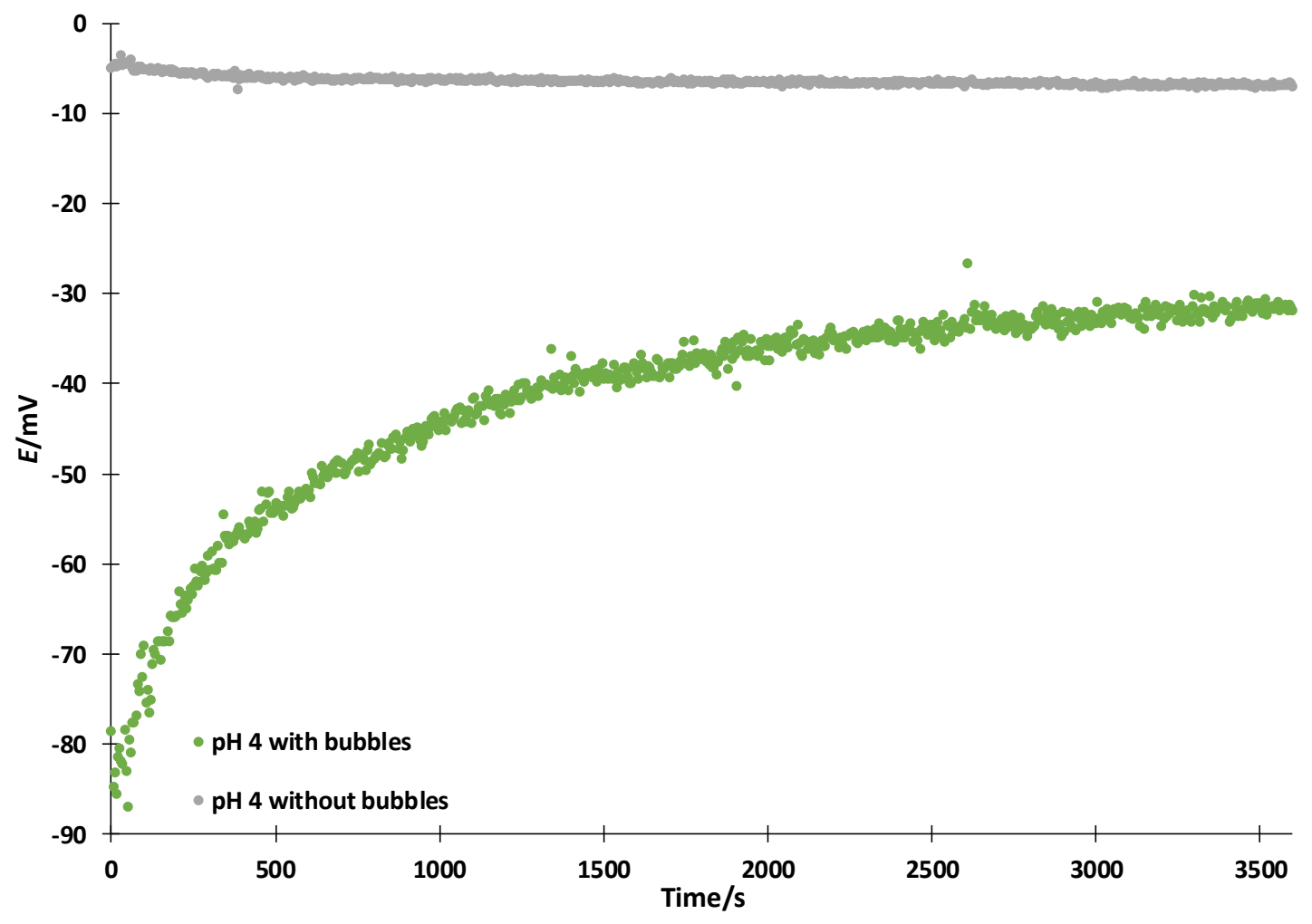

Figure 3. Time dependence of measured difference of potential with bubbles at the interface between IL and solution(s). Measured at LNE.

The measured potential difference is $23 \mathrm{mV}$ larger (corresponding to $0.4 \mathrm{pH}$ units) after $1 \mathrm{~h}$ of measurement when bubbles were detected at the interface between IL and the solution(s), than when no bubbles were present.

\subsection{Influence of the Instrument Used to Measure the Potential Difference: Potentiostat vs. pH Meter}

The influence of the instrument used to measure the potential difference is not easy to investigate since the institutes have often only one system within their facilities. For the present study, all the partners have pooled their data to see if there is any advantage in using a potentiostat or electrometer instead of a $\mathrm{pH}$ meter with differential input. Potentiostats are more expensive but have increased functionality.

Potentiostats and electrometers have one notable advantage compared to the model $713 \mathrm{pH}$ meter (two partners have this type of instrument) for unified $\mathrm{pH}$ measurements-it is much easier to detect potential measurement artifacts. The model $713 \mathrm{pH}$ meters are slow devices, thus, in the case of electrodes with very high impedance, they pick up noise from the environment. As a result, even with the differential amplifier, it is possible to obtain biased reading (up to $80 \mathrm{mV}$ from expected). Though the reading obtained can be very stable, they show a variation of less than $3 \mathrm{mV}$ a during $15^{\circ} \mathrm{min}$ period. With a potentiostat, it is possible to obtain data at high frequency (e.g., every $10^{\circ}$ $\mathrm{ms}$ ) and, in some cases, it is possible to see large potential oscillations of up to several hundred $\mathrm{mV}$. The oscillations represent the mains electricity noise $(\sim 50 \mathrm{~Hz})$. High frequency measurements can be used to measure the noise levels. This helps to find the noise source and reduce the noise level. For example, another instrument used in the lab can increase the noise level. The oscillations cannot be seen at low-frequency data collection. The oscillations are cancelled out during averaging, but the noise is not constant. This leads to the above-mentioned large differences in measured values. For comparison, the current PTB setup without a Faraday cage has a noise of around $30 \mathrm{mV}$. 
The measurements with aqueous standard buffers made at UT in 2020 are presented as an exemplary $\mathrm{pH}$ ladder in Figure 4. Every ladder has as minimum of three buffers and the number of single measurements made varies.

\begin{tabular}{|c|c|c|c|c|}
\hline Buffer pH & $\mathrm{pH}_{\mathrm{abs}}^{\mathrm{H}_{2} \mathrm{O}}$ & & $\Delta \mathrm{pH}$ & \\
\hline 10.00 & $9.97-$ & ${ }^{\uparrow} 96$ & & \\
\hline 7.00 & 7.00 & 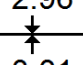 & & \\
\hline 4.00 & 3.99 & $\begin{array}{l}3.01 \\
+ \\
+\end{array}$ & $05-$ & 8.05 \\
\hline 2.00 & 1.94 & 2.04 & & \\
\hline
\end{tabular}

Figure 4. Example of a $\mathrm{pH}$ ladder with aqueous standard buffers. Buffer with $\mathrm{pH} 7.00$ was fixed. The $\mathrm{pH}_{\mathrm{abs}}^{\mathrm{H}_{2} \mathrm{O}}$ are the assigned $\mathrm{pH}_{\mathrm{abs}}^{\mathrm{H}_{2} \mathrm{O}}$ values.

Data from all obtained $\mathrm{pH}$ ladders were combined into Figure 5. The results from the first experimental realization [16] and unpublished validation results of the setup used in [20] are added for comparison. Both were performed using a saturated aqueous $\mathrm{KCl}$ salt bridge. In addition, some unpublished results from 2015 were added and measured with the same instrument as in FC.ID and UT in 2020, but with different cells. All measurements were made with Metrohm $713 \mathrm{pH}$ meters and a $\left[\mathrm{N}_{2225}\right]\left[\mathrm{NTf}_{2}\right]$ salt bridge.

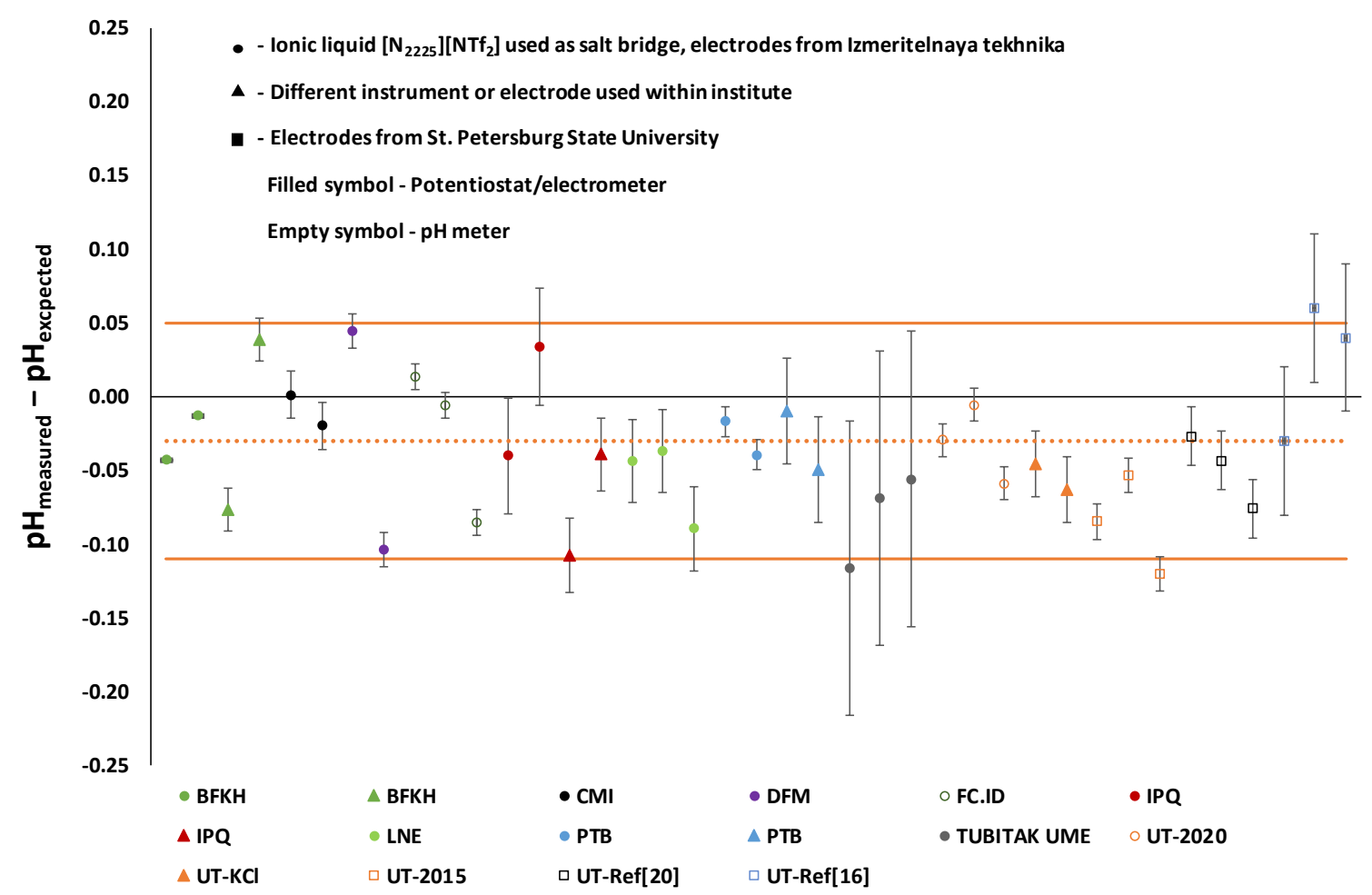

Figure 5. Validation results with standard aqueous buffers (See Table 1 for solutions that were used by different groups). The differences between the experimentally obtained $\mathrm{pH}$ and the expected buffer $\mathrm{pH}$ value (according to the label) are plotted. The uncertainty bars are the consistency standard deviations of the ladders. Within the series, the results are ordered from high to low $\mathrm{pH}$ of the buffer, and anchor points ( $\mathrm{pH} 7.00$ in all cases) are omitted from the graph. Orange lines represent the target uncertainty $(k=1)$. 
The consistency standard deviations of the obtained $\mathrm{pH}$ ladders are given in Table 4. Here, the standard deviation is smaller than the LJP cancellation assumption (approximately $0.1 \mathrm{pH}$ units) between different solvents.

Table 4. The consistency standard deviation of the obtained $\mathrm{pH}$ ladders.

\begin{tabular}{cc}
\hline Institution $^{a}$ & $s$ \\
\hline BFKH & 0.0001 \\
BFKH & 0.01 \\
CMI & 0.02 \\
DFM & 0.01 \\
FC.ID & 0.01 \\
IPQ & 0.04 \\
IPQ & 0.02 \\
LNE & 0.03 \\
PTB & 0.01 \\
PTB & 0.04 \\
TUBITAK UME & 0.10 \\
UT-2020 & 0.01 \\
UT-KCl & 0.02 \\
UT-2015 & 0.01 \\
UT [20] & 0.02 \\
UT [16] & 0.05
\end{tabular}

a Abbreviations of institutions are explained in affiliations.

An evaluation-type analysis of variance (ANOVA, one-factor analysis of variance) was made to test the effect of the instrument type used to measure the difference in potential between the electrodes. It was assumed that the difference between measured and expected $\Delta \mathrm{pH}$ values $(\mathrm{pH})$ has a normal distribution. The two types of instruments (potentiostat/electrometer vs. pH meter) have a different electronic architecture and lead to an initial hypothesis ( $\mathrm{H} 0$ ) that the nature of the instrument (the only factor of variability of interest) has an influence on the $\mathrm{pH}$ values. The validity of this hypothesis is tested using the statistic F test, which calls for the calculation of variances between groups (dispersion of means around the general average) and within groups (dispersion of data within each sample around its mean), denoted by $\mathrm{SC}_{\mathrm{F}}$ and $\mathrm{SC}_{\mathrm{R}}$, respectively. The results from [16] were not included, because that was the first experimental realization of the concept and the cell has improved a lot since then. The results of the ANOVA test are shown in Table 5.

Table 5. The results of the ANOVA test ${ }^{a}$.

\begin{tabular}{cc}
\hline Inter-Group Variance $\left(\mathrm{SC}_{\mathrm{F}}\right)$ & $\mathbf{0 . 0 0 6}$ \\
\hline Degree of freedom inter-group $\left(\right.$ dof $\left._{\text {inter }}\right)$ & 1 \\
Intra-group variance $\left(\mathrm{SC}_{\mathrm{R}}\right)$ & 0.060 \\
Degree of freedom intra-group (dof & 38 \\
F calculated & 3.398 \\
$\mathrm{P}$ & 0.073 \\
F critical $5 \%$ & 4.105 \\
\hline${ }^{a}$ With $\mathrm{F}=\left(\mathrm{SC}_{\mathrm{F}} / \mathrm{def}_{\mathrm{i}}\right)$ &
\end{tabular}

Table 5 shows that the calculated $\mathrm{F}$ value is lower than the critical value for a risk level of $5 \%$ and therefore the initial hypothesis is rejected. Thus, this analysis indicates that there is no significant difference in variances between results obtained using a $\mathrm{pH}$ meter and the ones obtained with a potentiostat. Therefore, both systems could be used reliably for $\mathrm{pH}_{\text {abs }}^{\mathrm{H}_{2} \mathrm{O}}$ measurement.

It is, nevertheless, important to mention that measurements in standard aqueous buffers cannot be used to demonstrate the advantage of using IL compared to classical salt bridge electrolytes if different solvents are involved. 


\subsection{Influence of the Pressure and IL Movement within the Cell}

The experimental system is also sensitive to any source of mechanical destabilisation of original conditions, such as opening or closing one or both sides of the cell. To test the influence of measurement conditions in an open cell versus a closed cell, experiments were completed with one (Figure 6) or both (Figure 7) sides closed to atmosphere.

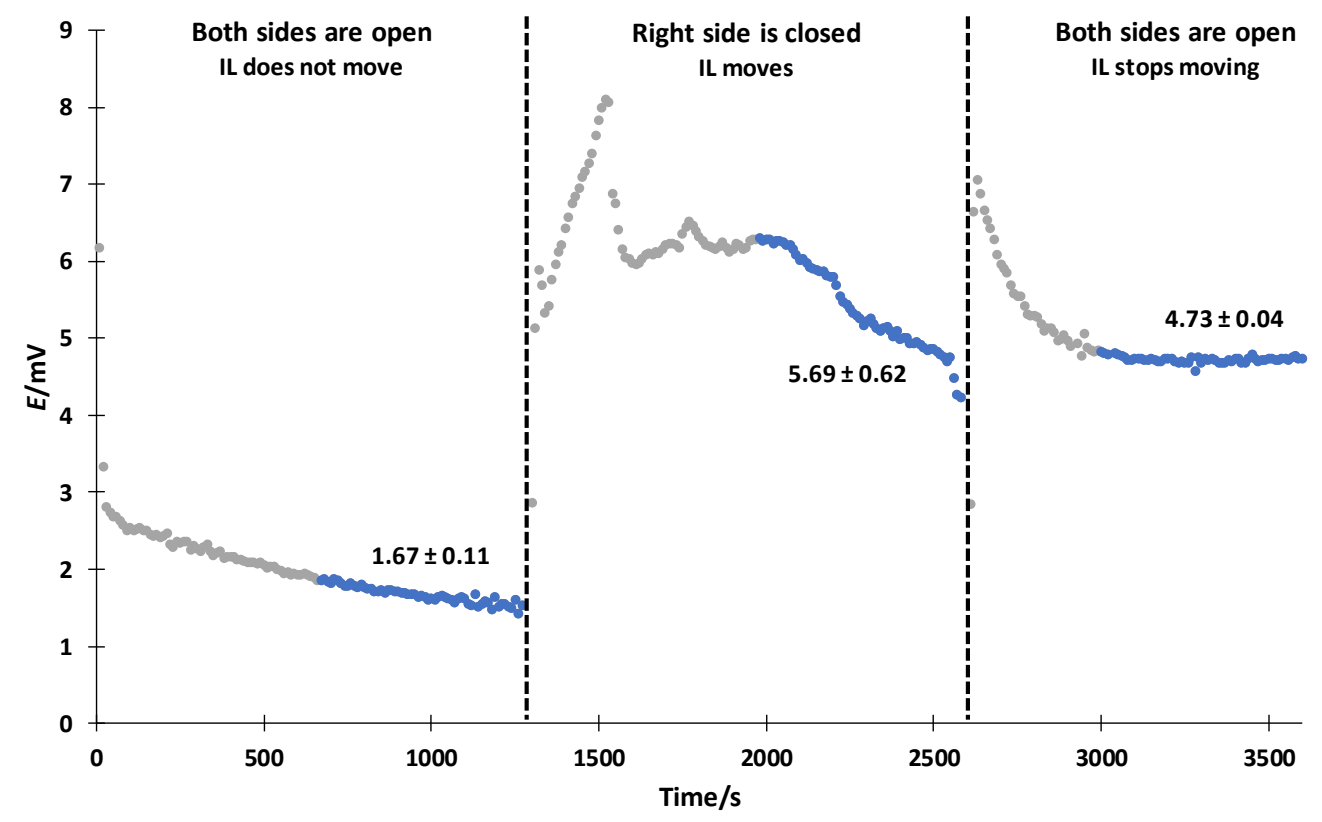

Figure 6. System $\mathrm{pH} 7$ vs. $\mathrm{pH}$ 7. Effect of closing one side to atmosphere. Measured at PTB.

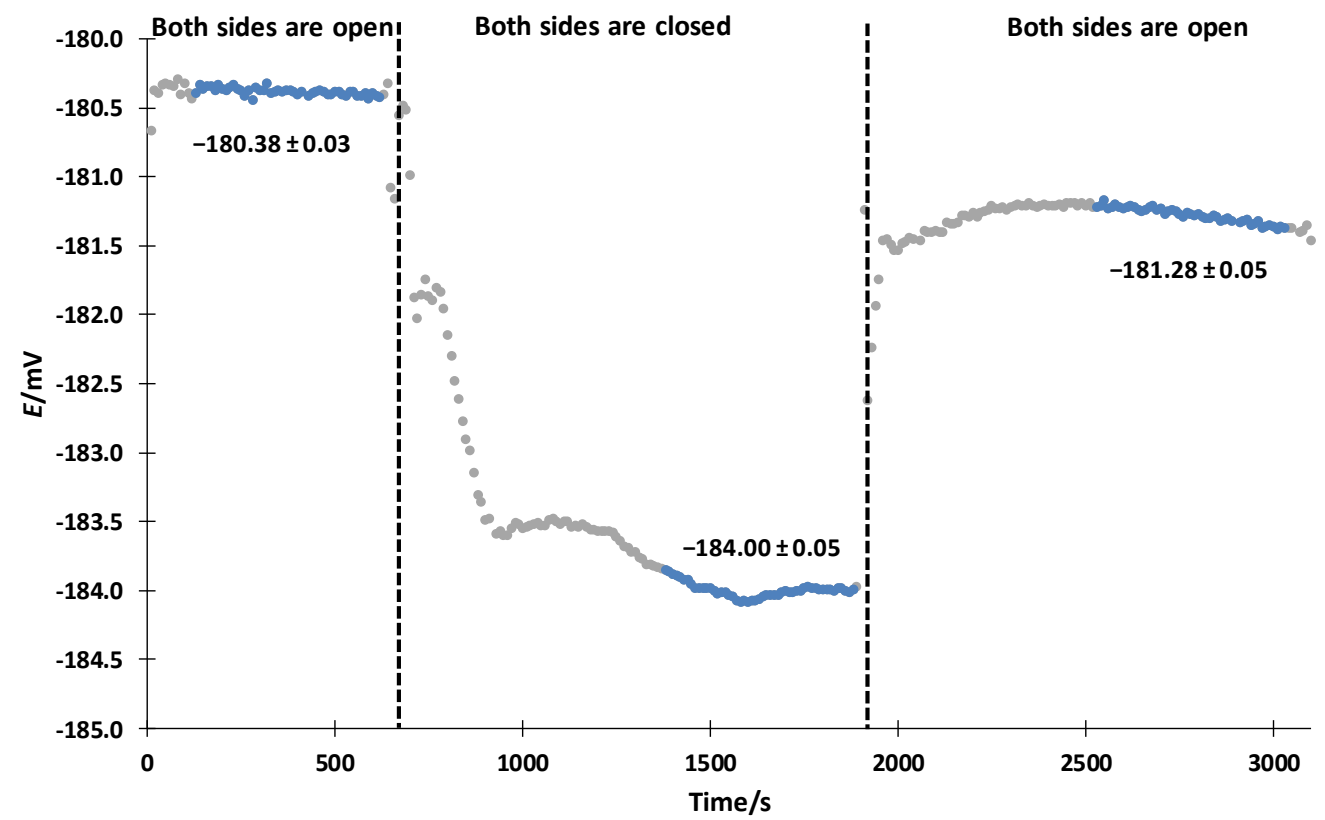

Figure 7. System pH 7 vs. pH 4. Signal stability if both sides are open or closed to atmosphere.

Measured at PTB.

System $\mathrm{pH} 9$ vs. $\mathrm{pH} 9$ behaved similarly to system $\mathrm{pH} 7$ vs. $\mathrm{pH}$ 7. In both cases, the difference between the fully open system and a system with one side closed is around $2 \mathrm{mV}$ to $3 \mathrm{mV}$, which could be due to the movement of the IL in the salt bridge. However, when the disturbance is removed and the system returns to its initial (open) state, the original readings of the measured potential are not recovered, suggesting an irremediable destabilization in junction symmetry. 
In the case of $\mathrm{pH} \mathrm{11,} \mathrm{the} \mathrm{difference} \mathrm{is} \mathrm{around} 3 \mathrm{mV}$ to $4 \mathrm{mV}$. The well-known sensitivity of high-basicity solutions to atmospheric $\mathrm{CO}_{2}$ might explain the results obtained for stronger alkaline buffers.

\section{Discussion}

The quality of $\mathrm{pH}_{\mathrm{abs}}^{\mathrm{H}_{2} \mathrm{O}}$ measurement is largely determined by the $\mathrm{pH}_{\mathrm{abs}}^{\mathrm{H}_{2} \mathrm{O}}$ system design. The influence of different cell designs on the reliability of the measurements was estimated in steps.

All the cells tested are suitable for unified acidity measurements, as is evident from Figure 5, where the majority of results lie within the target uncertainty or show significant overlapping uncertainty. The standard deviation of all the measured $\Delta \Delta \mathrm{pH}$ values is 0.04 . This validation highlights that the method is, to a large extent, independent of the user and the used equipment, including the cell geometry. The method is robust enough for a wider adoption of the concept. Most important is that all the cells are symmetrical, even if not perfectly.

In addition to cell symmetry, the quality (consistency standard deviation) of the fitted ladder data depends also on the electrodes and instrument. The instrument has a very important role in the quality of the data. The input impedance of the instrument must be high for a successful measurement. For example, the Agilent 3458A reference multimeter can only be used together with an impedance converter. Otherwise the obtained $\mathrm{pH}$ values can be even half a unit off. The type of the instrument is not important (Table 5). The UT results from 2015 with the $\left[\mathrm{N}_{2225}\right]\left[\mathrm{NTf}_{2}\right]$ salt bridge (UT-2015 in Figure 5) have a similar consistency standard deviation as the 2020 results from UT and FC.ID (UT-2020 and FC.ID in Figure) with the same instrument and salt bridge, but different cells. This comparison shows that the method gives reproducible results over a long time period and at different laboratories.

The measurement system is not perfectly symmetrical. The symmetry can be tested by measuring the same buffer on both sides of the cell (Figure 2). The closer the measured potential is to $0 \mathrm{mV}$, the more symmetric the system. This comparison includes all the effects, such as the cell, electrodes and IL. The more symmetric the cell, the less there is a need for measurement corrections and the more reliable the results.

The cell and its handling influence the quality of the data. The design of the cell is similar in all cases, but the cells are not identical. The differences in design influence the accuracy of the results and user friendliness. Glass blowing is done by hand and often the cell is not completely symmetrical, particularly the shape, i.e., diameter (around $1 \mathrm{~mm}$ ), length and uniformity of the salt bridge capillary. These minor differences are revealed while working with the cell, and the peculiarities of the specific cell must be considered. This might mean some changes in filling or cleaning procedures.

As for filling the cell, the capillary is filled first and then the test solutions are added to the cell compartments. Both compartments are filled simultaneously, otherwise the unbalanced pressure forces the IL out of the capillary. For the same reason, solutions added to the compartments must have an equal weight and not volume. Depending on the difference in amounts, the IL moves within or leaves the capillary. The IL movement causes unstable readings. Moreover, for a stable potential reading, it is necessary to keep both compartments connected to the atmosphere, allowing the atmospheric pressure to affect both compartments the same way. If one side of the cell is closed and the other side is open to atmosphere, the IL will move (Figure 6). If both compartments are closed, the potential changes, but is stable (Figure 7).

The two electrodes of the differential cell should be as similar as possible to their intercepts (and slopes). If this is not the case, then the cell is not completely symmetrical and a correction for the difference in intercepts must be applied. This introduces an uncertainty to the value of cell potential used for calculations of $\mathrm{pH}$. The correction does not work if also the slopes are different. A better approach is to measure the same pair of solutions again and exchange the electrodes in the buffers, while keeping the connections of electrodes the same and using the average of the obtained values. As a downside, this doubles the workload. 
Most of the $\mathrm{pH}$ differences plotted in Figure 5 are less than 0 , indicating that either the $\mathrm{pH}$ values of the anchor buffers are systematically higher, or the $\mathrm{pH}$ values of the remaining buffers are systematically lower. TUBITAK UME uses the lowest reported input impedance equipment. This might be one of the reasons for the experimental values having a large consistency standard deviation. Another reason is that they made measurements with only one polarity. BFKH, CMI, IPQ and UT used the average of opposite polarities to improve the quality of their data several times. In the cases of the two combined electrodes tested, only the signal from glass electrode part was used. Both combined electrodes can be used for unified acidity measurements, but they are not as good as metal solid contact glass electrode half-cells.

The liquid junctions of the salt bridge must be symmetrical for the LJP to be cancelled out. In an asymmetrical case, the LJP must be estimated or measured. If we have the same solvent with similar ionic strength on both sides, like with aqueous standard buffers, all salt bridge electrolytes should work well. However, as soon as the solvents on both sides are different, a salt bridge electrolyte with carefully selected properties is needed, such as $\left[\mathrm{N}_{2225}\right]\left[\mathrm{NTf}_{2}\right][22,23,25]$. During the cell filling process, air bubbles can form at the junction. If these are not removed carefully, they will cause problems. Large bubbles disconnect the circuit. This problem is easy to diagnose because the reading will be out of range of the instrument or extremely unstable. Small bubbles are harder to see, but they do not prevent completion of the measurement. Tiny bubbles at the junction lead to an unstable reading (Figure 3). Moreover, the immersion depth of the electrodes-albeit not significant for the present example-can have a small influence on the measurement results (less than $0.5 \mathrm{mV}$ ) if not symmetrical.

Finally, the storage of the electrodes plays a role. The more similar the storage solution to the solutions that are measured, the faster the electrode stabilization. If the electrodes are not kept in the same solutions as those to be measured, then the two electrodes will have different stabilization times. This effect can be overcome by a longer measurement time.

Step by step evaluation of the cell design and a measurement procedure regarding the reliability of the results help to find the uncertainty sources and establish traceability. With the use of standard aqueous buffers, we now can distinguish the influences coming from the sample to the ones from the setup. This knowledge is needed to move on to more complex matrices. The developed procedures can be used with nonaqueous solvents and aqueous-organic mixtures, where the advantage of using IL can be seen.

\section{Conclusions}

Unified acidity values ( $\mathrm{pH}_{\mathrm{abs}}^{\mathrm{H}_{2} \mathrm{O}}$ values) can be measured with various instruments and cell designs. All used experimental setups were found suitable for $\mathrm{pH}_{\mathrm{abs}}^{\mathrm{H}_{2} \mathrm{O}}$ measurements. The method is robust enough for a wider adoption of the concept, and the results from different setups are comparable. Symmetry of the measurement cell is important and helps to improve the accuracy of the measurement results, hence the $\mathrm{pH}_{\mathrm{abs}}^{\mathrm{H}_{2} \mathrm{O}}$ values. The workload halves if the electrodes used are similar.

Supplementary Materials: The following are available online at http://www.mdpi.com/2073-8994/12/7/1150/s1, Figure S1: The setup of BFKH; Figure S2: The setup of CMI; Figure S3: The setup of DFM; Figure S4: The setup of FC.ID; Figure S5: The setup of IPQ. (A) Symmetric cell for differential potentiometric measurements, (B) symmetric cell and glass electrodes inside Faraday cage (made in IPQ), (C) Keithley 6514 electrometer for differential potentiometric measurements and (D) whole setup; Figure S6: The setup of LNE; Figure S7: The setup of PTB; Figure S8: The setup of TUBITAK UME. (A) symmetrical measurement cell, (B) potentiometric titration system, (C) plug F differential amplifier, (D) circulated thermostatic water bath and (E) measurement cell-setup.

Author Contributions: Conceptualization, A.H., D.S., I.K. and I.L.; data curation, A.H.; formal analysis, A.H., B.A., D.N., R.Q., R.B., J.S., S.L., L.L., M.R. and A.S.; funding acquisition, D.S. and I.L.; investigation, A.H., D.S., B.A., D.N., R.Q., R.B., J.S., S.L., L.L., E.U., M.R. and A.S.; methodology, A.H., R.B., J.N. and I.L.; project administration, D.S. and F.B.; resources, F.C. Z.N.S., R.Q., L.R., F.B., L.L., M.V., L.D., I.K. and I.L.; supervision, Z.N.S., J.N. and I.L.; validation, R.Q., L.R., J.N., L.L., E.U., M.R., M.V. and V.R.; visualization, A.H.; writing-original draft, A.H.; Writing-review and editing, A.H., D.S., F.C., D.N., R.Q., F.B., J.N., S.L., L.L., M.R., A.S., L.D., V.R. and I.L. All authors have read and agreed to the published version of the manuscript. 
Funding: This research was funded from the EMPIR programme (project 17FUN09 “UnipHied”, www.uniphied.eu) co-financed by the Participating States and from the European Union's Horizon 2020 research and innovation programme. The work at UT was supported by the Estonian Research Council grant (PRG690) and by EU through the European Regional Development Fund under project TK141 "Advanced materials and high-technology devices for energy recuperation systems" (2014-2020.4.01.15-0011). FC.ID, whose work was developed in Centro de Química Estrutural, thanks Fundação para a Ciência e Tecnologia for funding under project UID/QUI/00100/2020. The APC was funded by MDPI.

Acknowledgments: The authors are thankful to Rouvim Kadis (VNIIM) and Teemu Näykki (SYKE) for inspiring discussions and help with obtaining suitable electrodes.

Conflicts of Interest: The authors declare no conflict of interest. The funders had no role in the design of the study; in the collection, analyses, or interpretation of data; in the writing of the manuscript, or in the decision to publish the results.

\section{Appendix A}

\section{Appendix A.1. Measurement Procedures Used}

BFKH: A Keithley 6430 Sub-Femtoamp remote sourcemeter/multimeter was used to measure the potential difference between the two glass electrodes and "Terminal" version 1.93b data logging software was used for data collection. The data were collected for at least $2 \mathrm{~h}$, the sampling interval was $3 \mathrm{~s}$ and the average of points from $1800 \mathrm{~s}$ to $7200 \mathrm{~s}$ was used. The electrode positions were switched, and the obtained two readings were averaged as the final potential that was used for minimization. The samples were thermostated at $25.00 \pm 0.02{ }^{\circ} \mathrm{C}$ using a water bath (Haake D8). BFKH used a Metrohm $6.0750 .100 \mathrm{Ag} / \mathrm{AgCl} 3 \mathrm{M} \mathrm{KCl}$ reference electrode for the calibrations. The suitability of Metrohm Solvotrode electrodes for unified acidity measurements were tested. No Faraday cage was used.

CMI: A Bio-Logic SP200 potentiostat with a low current module was used to measure the potential difference between two glass electrodes. The data were collected using EC Lab V11.25 software. The cell with electrodes was placed in a Faraday cage to eliminate the electromagnetic noise in order to obtain stable signal. The solutions were thermostated at $(25.00 \pm 0.05){ }^{\circ} \mathrm{C}$ using a thermostat LAUDA ALPHA RA 12. The sampling interval was $1 \mathrm{~s}$ and the data were collected for $15 \mathrm{~min}$. The values of $\Delta E$ extrapolated to the time of $0 \mathrm{~s}$ were used for the data analysis. The electrode positions were switched, and the obtained two readings were averaged to obtain the final potential.

DFM: A Zahner IM6ex potentiostat with the HiZ (high impedance) probe was used for the measurement of potentials, and dating logging was performed using the Thales V4.15 software. Data were collected over $1 \mathrm{~h}$ with a sampling interval of $10 \mathrm{~s}$, and only the data collected between $1800 \mathrm{~s}$ and $3600 \mathrm{~s}$ were used in data analysis. The cell, electrodes and high-Z probe were all placed inside a Faraday cage. Temperature stabilization to $25{ }^{\circ} \mathrm{C}$ was provided by a VWR AP15R-40 circulating refrigerator. A Radiometer REF421 Ag/ $\mathrm{AgCl}$ reference electrode was used for calibration of the glass electrodes.

FC.ID: A Metrohm $713 \mathrm{pH}$ meter was used for the differential measurement of potentials. No software was used for data collection. Data were collected for $90 \mathrm{~s}$ after $15 \mathrm{~min}$ stabilization at sampling interval of $10 \mathrm{~s}$. Non-thermostated cell measurements were performed at room temperature (lab average air temperature of $21.8^{\circ} \mathrm{C}$ ). A Mettler Toledo Inlab ${ }^{\circledR} 301 \mathrm{Ag} / \mathrm{AgCl} 3 \mathrm{~mol} \mathrm{dm}^{-3} \mathrm{KCl}$ reference electrode was used for the calibration experiments. No Faraday cage was used.

IPQ: An Agilent 3458A reference multimeter (resolution $8 \frac{1}{2}$ digits) with an impedance converter based on AD8627 (PTB development) and a Keitlhey 6514 electrometer were used for the potentiometric measurements. On both devices, the data were collected for $1 \mathrm{~h}$ (sampling interval was $20 \mathrm{~s}$ ) and the average of points collected between $1800 \mathrm{~s}$ to $3600 \mathrm{~s}$ was used as potential for the single run. The measurements were made at room temperature. The electrode positions were switched, and the obtained two readings were averaged to obtain the final potential. The glass cell and electrodes were in a Faraday cage. The glass electrodes were calibrated in aqueous standard buffers using a Metrohm 6.0733.100 Ag/ $\mathrm{AgCl} 3 \mathrm{M} \mathrm{KCl}$ reference electrode.

LNE: A Bio-Logic SP200 potentiostat equipped with a low current module was used to measure the potential difference between the two glass electrodes. The differential potentiometric setup was placed 
in a Faraday cage and an analog filtering at $5 \mathrm{~Hz}$ was carried out to limit the electromagnetic noise and obtain a smooth signal. The samples were thermostated at $(25 \pm 0.05){ }^{\circ} \mathrm{C}$ using a cryothermostat LAUDA ECO RE $2025 \mathrm{GN}$. The data were collected every $5 \mathrm{~s}$. The most stable data over a $15 \mathrm{~min}$ (around 200 points) period were used for subsequent data treatment.

PTB: A Keysight B2987A Electrometer/High Resistance Meter with Quick IV Measurement Software was used for measurements. The sampling interval was $10 \mathrm{~s}$. The data were collected for $1 \mathrm{~h}$ and the average of points $1800 \mathrm{~s}$ to $3600 \mathrm{~s}$ was used. A LAUDA Proline RP845 was used to maintain temperature at $25.0^{\circ} \mathrm{C}$. A Metrohm 6.0750.100 Ag/ $\mathrm{AgCl} 3 \mathrm{M} \mathrm{KCl}$ reference electrode was used for the glass electrode calibration experiments. A Faraday cage was not used. Metrohm EtOH-trodes, combined glass electrodes, were used for unified $\mathrm{pH}$ measurements. Only the signal from glass electrode part was used.

TUBITAK UME: A Metrohm 916 Ti-touch potentiometric titration system with a differential amplifier (Metrohm 6.5104.030) was used for the potentiometric measurements. The data were collected at intervals of $15 \mathrm{~min}$ for 2 or $3 \mathrm{~h}$ and the last two datasets were used. A Labo C200-H13 circulated thermostatic water bath was used to provide a stable temperature at $25.0^{\circ} \mathrm{C}\left( \pm 0.03{ }^{\circ} \mathrm{C}\right)$. A BASi MF-2052 $\mathrm{Ag} / \mathrm{AgCl}(3 \mathrm{M} \mathrm{NaCl})$ was used for the calibration experiments. A Faraday cage was not used.

UT: The experiments at UT were performed during three separate time periods: 2015, 2018, and 2020. Two measurement devices were used. Some measurements were performed with a Metrohm $713 \mathrm{pH}$ meter. The 2018 measurements were carried out with a Gamry Instruments Reference 3000 Potentiostat/Galvanostat/ZRA (zero resistance ammeter). Even more variation is to be found elsewhere in the measurement setup, as is evident from Table A1. A common feature for all three periods, however, is the saturated calomel reference electrode (Radiometer K401) which was used to calibrate ion-selective metal solid contact glass electrodes. Measurements were made at $25.0^{\circ} \mathrm{C}\left( \pm 1.0^{\circ} \mathrm{C}\right)$. The Rettberg cell that UT uses is based on the PTB cell. The only difference is the water jacket inlet and outlet positions, otherwise the cells are the same. 
Table A1. Unified acidity procedures used at UT.

\begin{tabular}{|c|c|c|c|c|c|}
\hline & [16] & [20] & 2015 & 2018 & 2020 \\
\hline Device & Metrohm & Metrohm & Metrohm & Gamry & Metrohm \\
\hline calibration of device & No & no & no & yes & no \\
\hline electrodes from & $\begin{array}{l}\text { St. Petersburg State } \\
\text { University }\end{array}$ & $\begin{array}{l}\text { St. Petersburg State } \\
\text { University }\end{array}$ & $\begin{array}{l}\text { St. Petersburg State } \\
\text { University }\end{array}$ & Izmeritelnaya tekhnika & Izmeritelnaya tekhnika \\
\hline glass cell & Figure $1 \mathrm{~A}$, in-house & Figure $1 \mathrm{~B}$, in-house & $\begin{array}{c}\text { Figure } 1 C \text {, same as in [21], } \\
\text { in-house }\end{array}$ & Figure $1 \mathrm{D}$, in-house & Figure 1E, Rettberg \\
\hline salt bridge position & Above & above & below & below & below \\
\hline Faraday cage & from $\mathrm{Al}$ foil & from Al foil & from $\mathrm{Al}$ foil & Gamry VistaShield ${ }^{\mathrm{TM}}$ & Gamry VistaShield ${ }^{\mathrm{TM}}$ \\
\hline auxiliary electrode & separate Pt electrode & $\begin{array}{l}\text { Pt wire soldered into } \\
\text { capillary }\end{array}$ & $\begin{array}{c}\text { Pt wire soldered into } \\
\text { capillary }\end{array}$ & none & $\begin{array}{l}\text { separate Pt wire inserted } \\
\text { from side port }\end{array}$ \\
\hline thermostated & Room & room & room & solution compartments & whole cell \\
\hline salt bridge electrolyte & saturated $\mathrm{KCl}$ & saturated $\mathrm{KCl}$ & {$\left[\mathrm{N}_{2225}\right]\left[\mathrm{NTf}_{2}\right]$} & saturated $\mathrm{KCl}$ & {$\left[\mathrm{N}_{2225}\right]\left[\mathrm{NTf}_{2}\right]$} \\
\hline pre-soaking (30 min) & No & no & no & yes & yes \\
\hline duration of meas. & $15 \mathrm{~min}$ & $15 \mathrm{~min}$ & $15 \mathrm{~min}$ & $35 \mathrm{~min}$ & $35 \mathrm{~min}$ \\
\hline data collection interval & None & none & none & $1 \mathrm{~s}$ & $3 \mathrm{~s}$ \\
\hline definition of potential & final data point & final data point & final data point & $\begin{array}{c}\text { average of last } 5 \text { min (301 } \\
\text { data points) }\end{array}$ & $\begin{array}{c}\text { average of last } 5 \text { min (101 } \\
\text { data points) }\end{array}$ \\
\hline used for minimization & $\begin{array}{l}\text { average of four or two } \\
\text { potentials with opposite } \\
\text { polarities }\end{array}$ & $\begin{array}{l}\text { average of two potentials } \\
\text { with opposite polarities }\end{array}$ & $\begin{array}{l}\text { average of two potentials } \\
\text { with opposite polarities }\end{array}$ & single potential & $\begin{array}{l}\text { average of two potentials } \\
\text { with opposite polarities }\end{array}$ \\
\hline
\end{tabular}




\section{Appendix A.2. Explanation of the "Ladder" Approach}

The "ladder" approach, used for assigning a $\mathrm{pH}_{\mathrm{abs}}^{\mathrm{H}_{2} \mathrm{O}}$ value to the measured buffers, relies on the measurements with cell II, where each half cell is filled in with a different $\mathrm{pH}$ buffer. An example of how to build such a ladder is shown with data from DFM.

First, the electrodes must be calibrated. This means that the potential of the glass electrode is measured against a reference electrode in standard aqueous buffers with known $\mathrm{pH}$ values. The results of measurements made at $25^{\circ} \mathrm{C}$ are shown in Table A2.

Table A2. The electrode characteristics.

\begin{tabular}{cccc}
\hline Electrode & Intercept/mV & Slope $/ \mathbf{m V}$ & $\mathbf{R}$ \\
\hline M1 & -1896.34 & -57.61 & 0.99996 \\
M6 & -1898.39 & -57.08 & 0.99993 \\
\hline
\end{tabular}

The next step is to measure potential between two glass electrodes in cell II. The measured potential, $\Delta E_{\text {measured }}$, is converted into $\mathrm{pH}$ difference with

$$
\Delta \mathrm{pH}_{\mathrm{abs}}^{\mathrm{H}_{2} \mathrm{O}}=\frac{\Delta E_{\text {measured }}}{\text { slope }_{\text {average }}}
$$

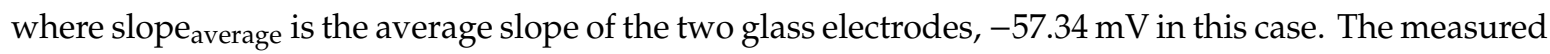
potentials together with the $\mathrm{pH}$ differences are shown in Table A3.

Table A3. Measured potentials $\Delta \mathrm{E}$ and their corresponding $\mathrm{pH}$ differences $\left(\Delta \mathrm{pH}_{\mathrm{abs}}^{\mathrm{H}_{2} \mathrm{O}}\right.$, exp $)$ for different pH buffer solution pairs.

\begin{tabular}{ccc}
\hline System & $\Delta E_{\text {measured }} / \mathbf{m V}$ & $\Delta \mathbf{p H}_{\mathbf{a b s}}^{\mathbf{H}_{2} \mathbf{O}}, \exp$ \\
\hline pH 7 vs. pH 4 & -177.00 & 3.09 \\
pH 7 vs. pH 4 & -178.76 & 3.12 \\
pH 7 vs. pH 4 & -179.09 & 3.12 \\
pH 7 vs. pH 4 & -177.11 & 3.09 \\
pH 7 vs. pH 4 & -177.69 & 3.10 \\
pH 9 vs. pH 4 & -304.64 & 5.31 \\
pH 9 vs. pH 4 & -304.30 & 5.31 \\
pH 9 vs. pH 4 & -305.06 & 5.32 \\
pH 9 vs. pH 4 & -305.64 & 5.33 \\
pH 9 vs. pH 4 & -305.67 & 5.33 \\
pH 9 vs. pH 7 & -128.39 & 2.24 \\
pH 9 vs. pH 7 & -127.71 & 2.23 \\
pH 9 vs. pH 7 & -127.78 & 2.23 \\
\hline
\end{tabular}

The experimental $\Delta \mathrm{pH}_{\text {abs }}^{\mathrm{H}_{2} \mathrm{O}}$ values are used to build the ladder. The sum of squares of differences between the assigned $\mathrm{pH}_{\mathrm{abs}}^{\mathrm{H}_{2} \mathrm{O}}$ values $\left(\Delta \mathrm{pH}_{\mathrm{abs}}^{\mathrm{H}_{2} \mathrm{O}}\right.$, assigned) and the experimental $\Delta \mathrm{pH}_{\mathrm{abs}}^{\mathrm{H}_{2} \mathrm{O}}$ values $\left(\Delta \mathrm{pH}_{\mathrm{abs}}^{\mathrm{H}_{2} \mathrm{O}}\right.$, exp) are minimized with the least-squares approach by varying the assigned values:

$$
\min _{i} \sum_{i}\left(\Delta \mathrm{pH}_{\mathrm{abs}}^{\mathrm{H}_{2} \mathrm{O}}, \exp , i-\Delta \mathrm{pH}_{\mathrm{abs}}^{\mathrm{H}_{2} \mathrm{O}} \text {, assigned, } i\right)^{2}
$$

The consistency of the scale (expressing the mutual consistency of the different relative acidity measurements) is evaluated with the consistency standard deviation of the scale $s$ defined as follows:

$$
s=\sqrt{\frac{\sum_{i}\left(\Delta \mathrm{pH}_{\mathrm{abs}}^{\mathrm{H}_{2} \mathrm{O}}, \exp , i-\Delta \mathrm{pH}_{\mathrm{abs}}^{\mathrm{H}_{2} \mathrm{O}}, \text { assigned, } i\right)^{2}}{n-m}}
$$


where $n$ is the number of measurement results on the scale and $m$ is the number of assigned values. An example of the minimization is given in Table A4 based on the results of Table A3. The resulting ladder is presented in Figure A1.

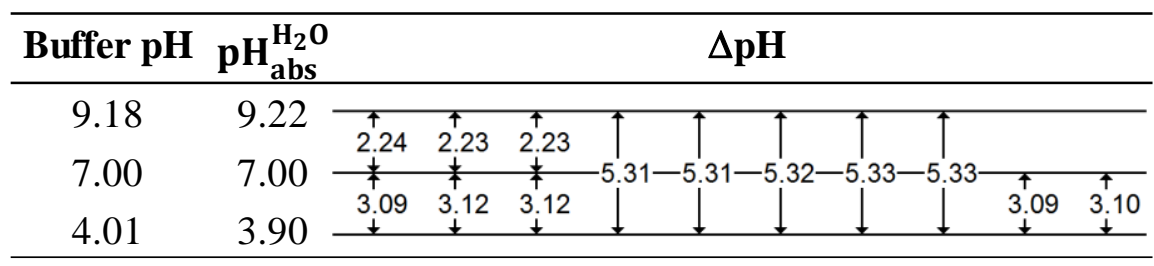

Figure A1. Example of a $\mathrm{pH}$ ladder with aqueous standard buffers. Buffer with $\mathrm{pH} 7.00$ was fixed.

If we take the first line in Table $\mathrm{A} 3$, then the $\Delta \mathrm{pH}_{\mathrm{abs}}^{\mathrm{H}_{2} \mathrm{O}}$, exp is 3.09 and the $\Delta \mathrm{pH}_{\mathrm{abs}}^{\mathrm{H}_{2} \mathrm{O}}$, assigned is $\mathrm{pH}=7-\mathrm{pH}=4$. The buffer with $\mathrm{pH}=7.00$ is an anchor value and is kept constant, while the other assigned values are changed during minimization to obtain the minimum sum of squares. MS Excel Solver add-in is used for the minimization.

Table A4. Minimization table.

\begin{tabular}{|c|c|c|c|c|c|c|c|c|}
\hline \multicolumn{2}{|c|}{$\mathrm{pH}_{\mathrm{abs}}^{\mathrm{H}_{2} \mathrm{O}}$, Assigned } & \multicolumn{6}{|c|}{$\Delta \mathrm{pH}_{\mathrm{abs}}^{\mathrm{H}_{2} \mathrm{O}}, \exp , \mathrm{i}-\Delta \mathrm{pH}_{\mathrm{abs}}^{\mathrm{H}_{2} \mathrm{O}}$, Assigned, $\mathrm{i}$ Used for Minimization } & \multirow[b]{2}{*}{0.003} \\
\hline 9.225 & -0.011 & -0.017 & -0.004 & 0.006 & 0.007 & \multirow[t]{3}{*}{0.014} & \multirow[t]{3}{*}{0.002} & \\
\hline 7.000 & -0.012 & 0.018 & 0.024 & -0.010 & 0.000 & & & \\
\hline \multirow{2}{*}{3.901} & & & & & & & & \\
\hline & \multicolumn{8}{|c|}{$\begin{array}{c}\mathrm{n}=13 \text { number of measurements } \\
\mathrm{m}=2 \text { number of assigned values }\end{array}$} \\
\hline
\end{tabular}

There are several ways to fill in the table rows. In this example, the single difference between experimental and assigned differences is calculated on the so-called working electrode (electrode connected to working electrode or ISE1 inlet, depending on the instrument) buffer row. For example, in the case of $\mathrm{pH}=7$ vs. $\mathrm{pH}=4$, the buffer $\mathrm{pH}=7$ is the so-called working electrode buffer. The assigned $\mathrm{pH}_{\text {abs }}^{\mathrm{H}_{2} \mathrm{O}}$ values shown in Table $\mathrm{A} 4$ are the ones obtained after minimization. It is important to note that the consistency standard deviation accounts for random effects influencing the measurement, but it does not account for such systematic effects that bias the $\mathrm{pH}_{a b s}^{\mathrm{H}_{2} \mathrm{O}}$ of a specific solution upwards or downwards.

\section{References}

1. Buck, R.P.; Rondinini, S.; Covington, A.K.; Baucke, F.G.K.; Brett, C.M.A.; Camoes, M.F.; Milton, M.J.T.; Mussini, T.; Naumann, R.; Pratt, K.W.; et al. Measurement of pH. Definition, standards, and procedures. Pure Appl. Chem. 2002, 74, 2169-2200. [CrossRef]

2. Activity (Relative Activity). Available online: https://doi.org/10.1351/goldbook.A00115 (accessed on 17 April 2020).

3. Pingarrón, J.M.; Labuda, J.; Barek, J.; Brett, C.M.A.; Camões, M.F.; Fojta, M.; Hibbert, D.B. Terminology of electrochemical methods of analysis (IUPAC Recommendations 2019). Pure Appl. Chem. 2020, 92, 641-694. [CrossRef]

4. Izutsu, K. Electrochemistry in Nonaqueous Solutions; Wiley-VCH Verlag GmbH \& Co. KGaA: Weinheim, Germany, 2002. 
5. Mussini, T.; Covington, A. Criteria for standardization of $\mathrm{pH}$ measurements in organic solvents and water + organic solvent mixtures of moderate to high permittivities. Pure Appl. Chem. 1985, 57, 865-876. [CrossRef]

6. Rondinini, S.; Mussini, P.; Mussini, T. Reference value standards $\mathrm{pH}$ measurements in organic solvents and water + organic solvent mixtures of moderate to high permittivities. Pure Appl. Chem. 1987, 59, 1549-1560. [CrossRef]

7. Barbosa, J.; Sanz-Nebot, V. Assignment of reference pH-values to primary standard buffer solutions for standardization of potentiometric sensors in acetonitrile-water mixtures. Fresenius J. Anal. Chem. 1995, 353, 148-155. [CrossRef]

8. Mussini, P.; Mussini, T.; Rondinini, S. Reference value standards and primary standards for pH measurements in D2O and aqueous-organic solvent mixtures: New accessions and assessments. Pure Appl. Chem. 1997, 69, 1007-1014. [CrossRef]

9. Barbosa, J.; Barron, D.; Marques, I. Assignment of $\mathrm{pH}_{\mathrm{S}}$ values of reference buffer solutions for standardization of potentiometric sensors in THF-water. Polyhedron 1999, 18, 3361-3367. [CrossRef]

10. Antonini, D.; Falciola, L.; Mussini, P.; Mussini, T. Medium effects, comparability and predictability of $\mathrm{pH}$-standards in aqueous+organic solvent mixtures: Behavior of the (ethylene carbonate+water) and (propylene carbonate+water) systems. J. Electroanal. Chem. 2001, 503, 153-158. [CrossRef]

11. Falciola, L.; Mussini, P.R.; Mussini, T.; Pelle, P. Determination of primary and secondary standards and characterization of appropriate salt bridges for $\mathrm{pH}$ measurements in formamide. Anal. Chem. 2004, 76, 528-535. [CrossRef] [PubMed]

12. Dumitrel, D.; Falciola, L.; Liotto, M.; Mussini, P.R.; Mussini, T.; Rossi, M. Determination of primary and secondary standards for $\mathrm{pH}$ measurements in N-Methylacetamide and its 0.50 mass fraction in admixture with water, with characterization of appropriate salt bridges. J. Chem. Eng. Data 2007, 52, 1595-1602. [CrossRef]

13. Falciola, L.; Fierro, A.; Mussini, P.R.; Mussini, T.; Rossi, M.; Dumitrel, D. Medium effects and determination of primary and secondary standards for $\mathrm{pH}$ measurements in (Glycerol + Water) solvent media at normal and subzero temperatures, with characterization of appropriate salt bridges t. J. Chem. Eng. Data 2009, 54, 286-293. [CrossRef]

14. Cox, R.A.; Yates, K. Acidity functions: An update. Can. J. Chem. 1983, 61, 2225-2243. [CrossRef]

15. Himmel, D.; Goll, S.K.; Leito, I.; Krossing, I. A unified pH scale for all phases. Angew. Chemie Int. Ed. 2010, 49, 6885-6888. [CrossRef] [PubMed]

16. Suu, A.; Jalukse, L.; Liigand, J.; Kruve, A.; Himmel, D.; Krossing, I.; Rosés, M.; Leito, I. Unified pH values of liquid chromatography mobile phases. Anal. Chem. 2015, 87, 2623-2630. [CrossRef] [PubMed]

17. Liquid Junction. Available online: http://goldbook.iupac.org/terms/view/L03584 (accessed on 17 April 2020).

18. Bates, R.G. Determination of pH: Theory and Practice, 2nd ed.; John Wiley \& Sons: New York, NY, USA; London, UK; Sydney, Australia; Toronto, Japan, 1973; ISBN 0-471-05647-2.

19. Popovych, O.; Bates, R.G. Estimation of medium effects for single ions in non-aqueous solvents. CRC Crit. Rev. Anal. Chem. 1970, 1, 73-117. [CrossRef]

20. Liigand, P.; Heering, A.; Kaupmees, K.; Leito, I.; Girod, M.; Antoine, R.; Kruve, A. The evolution of electrospray generated droplets is not affected by ionization mode. J. Am. Soc. Mass Spectrom. 2017, 28, 2124-2131. [CrossRef] [PubMed]

21. Lõkov, M.; Tshepelevitsh, S.; Heering, A.; Plieger, P.G.; Vianello, R.; Leito, I. On the basicity of conjugated nitrogen heterocycles in different media. European J. Org. Chem. 2017, 2017, 4475-4489. [CrossRef]

22. Radtke, V.; Ermantraut, A.; Himmel, D.; Koslowski, T.; Leito, I. The Ideal ionic liquid salt bridge for the direct determination of gibbs energies of transfer of single ions, Part I: The concept. Angew. Chemie Int. Ed. 2018, 57, 2344-2347. [CrossRef] [PubMed]

23. Ermantraut, A.; Radtke, V.; Gebel, N.; Himmel, D.; Koslowski, T.; Leito, I. The ideal ionic liquid salt bridge for direct determination of Gibbs Energies of transfer os single ions, part II: Evaluation of the role of ion solvation and ion mobilities. Angew. Chemie Int. Ed. 2018, 57, 2348-2352. [CrossRef] [PubMed] 
24. Veigure, R.; Lossmann, K.; Hecht, M.; Parman, E.; Born, R.; Leito, I.; Herodes, K.; Kipper, K. Retention of acidic and basic analytes in reversed phase column using fluorinated and novel eluent additives for liquid chromatography-tandem mass spectrometry. J. Chromatogr. A 2020, 1613, 460667. [CrossRef] [PubMed]

25. Radtke, V.; Gebel, N.; Priester, D.; Ermantraut, A.; Bäuerle, M.; Himmel, D.; Koslowski, T.; Leito, I. Krossing the ideal ionic liquid salt bridge for the direct determination of Gibbs Energies of transfer of single ions, part III: Evidence and Implications of the absence of solvent-solvent interactions. Angew. Chemie Int. Ed. Submitted.

(c)

(C) 2020 by the authors. Licensee MDPI, Basel, Switzerland. This article is an open access article distributed under the terms and conditions of the Creative Commons Attribution (CC BY) license (http://creativecommons.org/licenses/by/4.0/). 